\title{
Challenges to Financial Audit in Enterprises of Public Interest
}

\author{
Plamen Kimonov Iliev (PhD), Chief Assistant \\ New Bulgarian University, Department of Economics, Sofia
}

Received 14 July 2018 • Revised 25 July 2018 • Accepted 3 September 2018

\begin{abstract}
The material examines the new moments set forth in the Regulation EU/537/2014 and Directive $\mathrm{EU} / 56 / 2014$, regulating its application Independent financial auditing, including in public interest. Attention is drawn to the new moments in our relationship, namely joint audit, rotation of auditors, new reporting moments, joint auditors and the increased powers of the Public Oversight Commission on work on registered auditors.
\end{abstract}

Keywords: financial audits, shared auditors, public enterprises interest, rotation.

On 29 November 2016, the new Independent Financial Audit Act (IFAA) was promulgated in the State Gazette, which fully transposed the requirements of Directive EU/43/2006, as amended by Directive EU/56/2014 and Regulation EU/537/2014. It contains substantial changes, in particular with regard to the duties of audit committees, as well as auditing in Public Interest Enterprises (PIE). In this respect, in 2018, for the first time, the new requirements of the law were applied in the annual financial report approvals for 2017, which introduced a number of new principles, such as shared audit, mandatory rotation of registered auditors, a ban on certain services, and wage restraints services other than auditing. Audit committees are already subject to oversight by the Commission for public supervision of registered auditors. following:

Public interest entities are defined in the Accountancy Act (AA), and these are the

- undertakings whose transferable securities are admitted to trading on a regulated

market in a Member State of the European Union;

- credit institutions;

- insurers and reinsurers;

- pension insurance companies and the funds managed by them;

- investment intermediaries, which are large enterprises within the meaning of the $\mathrm{AA}$;

- collective investment schemes (CIS) and management companies within the meaning of the Law on the activity of CIS and other collective investment undertakings which are large enterprises within the meaning of the AA;

- financial institutions within the meaning of the Law on Credit Institutions, which are large enterprises within the meaning of the Insurance Act;

(C) Authors. Terms and conditions of Creative Commons Attribution 4.0 International (CC BY 4.0) apply. Correspondence: Plamen Iliev, New Bulgarian University, Department of Economics, Sofia, BULGARIA. E-mail: kaviplas@abv.bg. 
- "Holding BDZ" Ltd and its subsidiaries; National Railway Infrastructure Company;

- commercial companies whose main business is to produce and/or to transfer and/or sell electricity and/or heat and which are large enterprises;

- commercial companies whose main business is to import and/or transport, and/or distribute and/or transit natural gas, and which are major AA enterprises;

- Plumbing contractors within the meaning of the Water Supply and Sewerage Services Regulation Act, which are medium and large enterprises.

All PIE must have an already established audit committee under the IFAA, which strengthens the importance of audit committees in public interest entities. Within six months of the entry into force of the law, by the end of April 2017, these companies had to comply with the new requirements, having already set up audit committees and defining its functions, rights and responsibilities in relation to the financial audit, internal control and internal audit, as well as its relations with the company's management bodies.

By comparing the current scope of public interest entities with that of the former (in the IFAA), it is noticeable that the telecommunication companies are not included in the present scope. The new version defines companies engaged in the production and/or transmission of electricity and/or heat and those engaged in the import and/or transmission and/or distribution and/or transit of natural gas as such, from public interest only if they are large, according to the requirements of the Accountancy Act. Within the scope of public interest entities, collective investment schemes and management companies, as well as financial institutions, are included only in cases where those enterprises meet the criteria for "large" within the meaning of the law. Public water power plants were included in the scope of public interest companies regardless of their size. For the reporting period during which a public interest entity ceases to meet the requirements for the period, the same as at 31 December of the current year is considered to be an undertaking in the public interest.

The new requirements in the IFAA provide for the introduction of so-called shared audit when it comes to public interest entities. These companies will also be able to use a single audit company for a maximum of 7 years. In the discussions and debates before the adoption of the law, according to the Finance Ministry, the changes will bring about harmonization of the Bulgarian legislation with the European legislation. The main objectives are to strengthen the protection of investors and the quality of the audits carried out.

One of the main changes is the introduction of the obligation for two audit firms to audit the annual financial statements of public interest companies and then to prepare a joint report. According to the Ministry of Finance, the texts were introduced according to a prescription of the European Commission in its 2010 Green Paper entitled Audit policy: Lessons learned from the crisis. The aim is to break the dominant position of the major auditors and to provide the possibility for non-systemic companies to enter the financial sector and reduce the concentration of audit services, which entails the creation of systemic risk in the sector.

Against the introduction of this requirement, then the banks said that the shared audit would increase banks' spending by about 25\%, but according to the draft bill, rising costs can not be an argument against joint audits, and the argument is better to costing someone's business, but saving money for citizens and society.

In this regard, the Ministry of Finance recalled the situation in 2014, when due to weaknesses in the audit and oversight, bankruptcy of the fourth largest bank in Bulgaria Corporate Commercial Bank (CCB) took place. The strengthening of the supervision of the financial system is on the recommendation of the European Commission to Bulgaria from the beginning of 2015 and the International Monetary Fund (IMF) has also recommended strengthening the supervision processes and drawing lessons from the CCB case. 
Amendments introduced and so-called mandatory rotation of audit firms. Public interest companies will be able to work with one auditor for a maximum of 7 years. Representatives of foreign business organizations insisted on using the maximum allowed term in the European directive -10 years. However, the Ministry of Finance ruled that the risks to the independence of auditors of public interest entities have been reduced by this deadline.

The rotation of auditors is one of the options to achieve to a large extent independence and objectivity. This issue became relevant in the United States in 2002 with the adoption of the Sarbanes-Oxley Act, which is in response to corporate accounting scandals with Enron WorldCom.

Two forms of rotation are known:

- the key auditor or auditor responsible;

- the audit firm as a whole.

The rotation of audit firms has both positive and negative sides.

The positive ones are that it reduces auditing risk, reduces closer auditor/employee relationships and improves the quality of audit services.

Negative is the increase in the cost of validating the annual financial report, restricts specialization and experience, increases auditing errors, reduces incentives to increase efficiency and quality, reduces understanding and knowledge of the enterprise, and so on.

There are a few more changes to this effect. A minimum statutory audit period of three years is introduced, tax audits are granted to the audited entity by the registered auditor, and restrictions are placed on the audited entity's revenue from non-audit services in the public interest as well as on cases of the revenue from this. Where, for three or more consecutive financial years, an auditor provides to a publicly-owned establishment non-audit services, the total amount received for such services may not exceed $70 \%$ of the average paid during the last three consecutive financial years for a statutory financial audit in the audited enterprise. The changes are also the following:

- The PIE auditor's report is in a different format and volume - apart from other changes, it should also include a description of key audit questions;

- the Registered Auditor must prepare and submit to the Audit Committee an additional report (in addition to the Audit Report). This also applies to the group auditor - an additional report is provided to the audit committee of the parent. At the request of a competent authority supervising the PIE, the registered auditor shall immediately submit the relevant supplementary report;

- when conducting a statutory audit at the PIE, the registered auditor should inform the management and the audit committee of the entity of any circumstances that are or would impair its independence in the performance of the audit engagement.

- the PIE auditor should promptly report to the relevant body of the entity and to the Commission for public supervision of registered auditors any information that has caused or is likely to cause one of the following consequences: (1) a material breach of the regulatory provisions which lay down licensing conditions or which specifically regulate the performance of the PIE activities; (2) a material threat or suspicion of continuing the activity of the PIE; (3) response from audit opinion, negative or qualified audit opinion. The auditor is required to provide an additional report to the audit committee.

In 2017, the Commission for public supervision of registered auditors and the Institute of Certified Public Accountants have developed Guidelines for the implementation of a shared audit in PIE aimed at assisting registered auditors, business executives and audit committees in carrying out a joint audit to achieve the objectives of the financial audit, auditing standards. 
The Guidelines set out the key principles and approaches of the shared audit, including the role and responsibilities of joint auditors, additional audit procedures, communication and auditing documentation requirements when performing joint audits of individual or consolidated financial statements of enterprises under the Act of Independent Financial Audit.

They think:

- shared audit is a commitment to a mandatory financial audit where two or more registered auditors - natural persons and / or audit firms have undertaken to audit a company's financial statements through shared work and jointly issue an audit report on that report, are jointly and severally liable for the expressed audit opinion; - a shared auditor is a registered auditor (natural person or auditor company) that has undertaken a joint audit commitment;

- a balanced distribution of work is such a distribution of work between the joint auditors where the ratio of the planned hours for the implementation of the audit procedures to cover areas with significant risk is not more than one third (for example, for two joint auditors a balanced distribution of work is in proportion to $60 / 40$ percent of the total hours planned); the allocation for simultaneous execution of shared audits of individual and consolidated financial statements is made separately according to the terms in the letters of assurance for each of the audit engagements.

Joint auditors should prepare and submit proposals for competitive auditing in accordance with the requirements of the Independent Financial Audit Act, International Auditing Standards (ISAs) issued through the International Standards on Auditing and Standardization Standards and the Code of Ethics for Professional Accountants (CEPA) issued through the International Ethics Standards Board for Accountants of the International Federation of Accountants. Under the terms of the request for an audit proposal, the shared auditor may propose the joint auditor may offer shared audit services individually or together with another auditor(s).

Each joint auditor is required to be equally responsible for complying with the independence requirements and other ethical requirements under the IFAA, as well as the competence and expertise required to perform the joint audit. He has to make sure that any other joint auditor has been selected in accordance with these requirements. It has the right to refuse joint work with another selected auditor or to reject the engagement as a whole on the basis of evidence of non-compliance or refusal of co-operation by the other auditor, regardless of the manner in which the audit proposal is made under the provisions of Independent Financial Audit Act.

Sentient auditors are jointly responsible for accepting the client and engaging in accordance with the Independent Financial Audit Act and the Code of Ethics for Professional Accountants. Client acceptance and engagement procedures are implemented jointly, including endorsement of the final decision.

The terms of the shared audit engagement shall be governed by a joint audit engagement letter that shall be agreed and signed by the joint auditors in accordance with the requirements of the applicable auditing standards. Any other arrangements and terms, such as financial or specific legal terms that are not related to the arrangements in the letter and are not in contradiction with the applicable auditing standards and the law, may be agreed by the joint auditor with the management of the entity individually in a separate agreement.

The audit engagement letter also mentions the terms and procedure for sharing work between the joint auditors, as well as resolving any differences of opinion or disputes between them.

The joint auditors are jointly and severally responsible for the performance of the audit engagement and for the audited opinion, in compliance with the requirements of applicable 
ethical norms, for Independence, established by the FIFG, the ETUC and the applicable auditing standards.

The nature, timing and extent of the work to be performed in a joint audit is the same as when performing a stand alone audit engagement.

Therefore, they agree and jointly develop a common audit strategy and engagement audit plan setting a common materiality level and uncorrected deviation profile for the entire engagement as well as other materiality levels in line with applicable audit standards. In case of disagreement resulting from different methodologies applied by the auditors, the lowest relevant materiality level is used.

At the planning stage, the joint auditors agree on the distribution of the work to be done to implement the audit engagement. Client acceptance and engagement procedures, risk assessment, engagement quality control, and communication with those charged with governance and evaluation of audit results can not be distributed and should be implemented jointly.

The Joint Auditors shall draw up a written memorandum for the allocation of audit procedures. Such allocation could be made as follows:

- understanding the Entity and risk assessment - implemented jointly; audit strategy and audit plan - implemented jointly;

- audit procedures - are performed separately by the joint auditors of the basis of

the agreed work distribution;

- analytical procedures at the end of the audit engagement - performed jointly;

- audit report - prepared jointly.

Part of the audit work involves getting information and explanations from the management. These procedures are performed jointly by the joint auditors, except if they do not agree in writing on a specific allocation of this to a specific joint auditor to obtain the necessary information and explanations from the management and to provide them with the relevant other joint auditor.

Each shared auditor is required to satisfy himself that the other joint auditors have performed their part of the joint audit work in accordance with applicable auditing standards and to provide the other joint auditors with all the information about any deviation, misstatement or reporting from the audited entity.

The joint auditor analyzes the areas in the financial statement with assessed significant risks and determines the scope and degree of peer review on the work of the other joint auditors.

When a shared auditor considers that the work of another joint auditor is inadequate or can not rely on it, he should write in writing to the other joint auditor to arrange for the performance of the additional work that is required.

The joint auditor should identify and implement policies and procedures for differences of opinion with another joint auditor. Procedures should ensure early identification of differences of opinion, provide clear guidance on the steps to follow, and require documentation of the resolution of differences and the implementation of the conclusions reached.

If a controversial issue can not be solved by the joint auditors, the responsible auditors should document in their audit file the disagreements on material audit issues and / or areas of judgment and the reasons for doing so. This document must contain: a description of the controversial issue; applicable auditing standards; proposed resolution of the problem; information about the actions taken to resolve the problem.

When differences of opinion can not be resolved, the joint auditors promptly inform the management, the Audit Committee and others charged with governance. 
It is of great importance that each joint auditor should make the necessary efforts to resolve differences with other joint auditors prior to the issuance of the audit report. In rare cases where this is not possible and refers to significant differences that would lead to a modification of the audit opinion, the IFAA requirements are applied.

The shared auditors shall implement the policies and procedures adopted for the engagement quality control review in compliance with the IFAA requirements and applicable auditing standards.

The quality control review should be performed, documented and completed before the date of the joint audit report.

Joint auditors express or form a final unified audit opinion as to whether the financial statements are prepared and presented in all material respects, in accordance with the applicable financial reporting framework. In the event of differences of opinion, the joint auditors shall implement policies and procedures that have been agreed in advance.

The communication between the shared auditors shall be implemented on an agreed plan and in an effective manner consistent with the size and complexity of the audit engagement. Joint auditors should establish an appropriate communication process between themselves in the planning phase of the joint audit by documenting it.

Written communication with management and those charged with governance is jointly prepared and signed by all joint auditors.

Joint auditors should comply with the requirements for communication with the competent authorities supervising the activities of audited entities arising from current legislation and applicable auditing standards.

The requirements of applicable auditing standards for documentation and storage of audit file engagement and applicable legal and regulatory requirements for documentation. All documents certifying joint work are signed by each of the jointly responsible auditors and each joint auditor collects, maintains and archives a complete audit engagement file.

\section{Instead of concluding}

When we talk about the benefits or the positive aspects of the application of the financial audit, including auditing in public interest entities, we should first of all say:

- Support for accountants - the best effect is when financial audit work begins before the end of the financial year so that there is time to be done if adjustments are needed in the coverage of transactions or events;

- Next, security for management - independent highly qualified specialists auditors inspect all processes and their correct reporting in the financial statements. Confirms the honest and faithful work of the accounting department and the compiler of the report. So managers are confident that the reports are a true reflection of the financial situation, or they are shown areas that need improvement, and how to apply appropriate changes and adjustments;

- The audit may reveal inaccuracies and inconsistencies in the records of an organization, which may be signs of a weak financial organization;

- The audit also applies to the protection of the owners - the owners receive confirmation from an independent party about the reliability of the financial statements, information about any mistakes, misuses or frauds committed by persons employed in the company's business, as well as its management;

- The audit provides sufficient and reliable information to all other stakeholders of the business, such as financial institutions, investors, contractors, contracting authorities; 
- The audit presents and leads to greater trust for the creditors and business partners of the company - for the business community, regular audits enhance the company's reputation and make it a desirable business partner. Financial audits are a prerequisite for lower investment risk for almost every type of business credit.

\section{Acknowledgements}

This research did not receive any specific grant from funding agencies in the public, commercial, or not-for-profit sectors.

\section{Conflict of interest: none.}

\section{References}

... (2016). Comments of MoF, KPMG, BNB on Independent financial audit Act.

Genov, Sl. (2016). Rotation and independent financial audit. Izvestia, Varna, University of Economics.

Guidelines for the implementation of a shared audit (2017). Institute of Certified Public Accountants and Commission for public supervision of registered auditors.

... (2018). Independent financial audit Act - SG-95-29.11./2016, amended SG-15/2018.

www.minfin.bg

www.ides.bg

www.bulnao.goverment.bg 
P. K. Iliev - Challenges to Financial Audit in Enterprises of Public Interest

C O A $\mathbf{s}$ 